\section{OSTEOARTHRITIS OF THE KNEE}

TREATMENT BY LOCAL INJECTION OF SALICYLATE COMPOUNDS

\author{
BY \\ K. A. ROSS, M.B., Ch.B.
}

J. H. MAYER, T.D., M.B., F.R.C.S.

AND

MARGARET M. SHEPHERD, M.B., B.Sc, F.R.C.S.

From the Orthopaedic Department, Pembury Hospital, Pembury, Kent

Many attempts have been made to relieve the symptoms of osteoarthritis by injection into the affected joints, and a wide variety of materials have been tried: König (1932) used iodized oil ; Thomson (1933) used Pregl's solution of iodine with sodium bicarbonate and sodium chloride in a watery solution; Andernach and Löhr (1936) used pure liver injections. These were for the most part small series, and though the respective authors claimed encouraging results none of their methods has found general acceptance.

Waugh (1938) claimed that the synovial fluid in traumatic effusions and rheumatoid arthritis was more alkaline than normal tissue fluid, and reported uniform improvement in such cases from aspiration followed by the intra-articular injection of an acid solution of lactic acid and procaine at $p H$ 5. Later, Waugh (1945) reported a series of 26 consecutive cases of monarticular osteoarthritis of the hip treated by injections of a lactic acid and procaine mixture at $\mathrm{pH} 5.8$, in which over $50 \%$ followed up for more than two years were said to have obtained enough help to carry on their normal occupations.

Crowe (1944), accepting Waugh's $p H$ findings, used a solution of acid sodium phosphate in isotonic saline, claiming that this had a more prolonged effect than lactic acid on the $\mathrm{pH}$ of the joint fluid. In 93 cases of osteoarthritis he claimed excellent results in about $20 \%$ and improvement in every one of the remainder. Mawson (1946), Heald and Martin (1947), and Paraf, Abaza, and Peretz (1949) all reported favourable results with Waugh's solution.

Other authors, however, were far more critical. Baker and Chayen (1948) compared the results after intraarticular injections of Waugh's solution with those produced by solutions of procaine in water, sodium phosphate solution in water at $\mathrm{pH} 7.6$, and normal saline. The results were not significantly different and they concluded that the acid solution produced no benefit compared with those of physiological $\mathrm{pH}$. Nicholson (1948) criticized Waugh's $p H$ estimations, and Kron (1948) reported encouraging results from the intra-articular injection of an isotonic solution of sodium bicarbonate in 15 cases. Lawther (1949) produced equal results in osteoarthritic hips by intra-articular injections of lactic acid and procaine solution, or procaine hydrochloride solution alone.

Desmarais (1952) recorded detailed results in the treatment of 189 cases of osteoarthritis of the hip and knee. Three groups were injected respectively with alkaline procaine solution at $p \mathbf{H}$ 7.4, Waugh's lactic acid procaine solution at $p \mathrm{H} 5.4$ and saline at $p H$ 7.2; in the fourth group the affected joint was needled with no injection. The same procedure was repeated several times in each case. Some members in each group improved, but the differences between them were not statistically significant. The $\mathrm{pH}$ of the synovial fluid was investigated in 10 of the osteoarthritic knees before treatment, and in every case it was found to be normal. No large or lasting change in $p \mathrm{H}$ followed the lactic acid injections, and the author remarked that synovial fluid acts as a strong buffer.

\section{Present Investigation}

This investigation is based on the work of $G$. Laughton Scott. After seeing several arthritic patients who had derived benefit from repeated intra-articular injections of an oily preparation by a foreign physician who refused to divulge its formula, Scott started a protracted investigation of various oils, and later of other substances dissolved in oil. He concluded that none of the oils tried alone produced any benefit, but he found that the use of oil as solvent for other substances injected into joints prolonged their local action and reduced their rate of excretion. After trying many such substances he published (Scott, 1943) a series of 96 consecutive cases of osteoarthritis and other "rheumatic" disorders treated by local injection of $10 \%$ benzyl salicylate in oil, with $79 \%$ good results. The number of osteoarthritic cases was not specified. Scott continued to use benzyl salicylate in oil until his death, but modified the formula to that which has been used in the present investigation. Benzyl salicylate was evidently chosen because it is the most readily oil-soluble salt of salicylic acid. For intraosseous injection Scott tried various watery salicylate solutions. The one used in our investigation was that favoured by him for this purpose in his later years.

Elkin (1945), using $10 \%$ benzyl salicylate solution in oil, recorded very encouraging results in a series of 25 patients with severe osteoarthritis of the hip- and knee-joints. Although the number is small, Elkin's figure of $80 \%$ improvement is similar to our own. Broadman (1954) in the United States wrote enthusiastically of the results in osteoarthritis and fibrositis, though he quoted no figures.

The cases here recorded received all their injections from K.A.R.; who worked with Scott during his latter years and has continued to use his technique since his death. The assessment before and after treatment was conducted by M. M. S., who undertook the original investigation on behalf of the Dora Garrod Thomas Trust. This is a completely unselected series of cases ; every new patient attending the orthopaedic out-patient department in whom osteoarthritis of one or both knees was diagnosed was referred for assessment and treatment. Of the 57 patients who were referred in this way, four failed to attend for treatment. The remaining $53 \mathrm{had}$ a full course of treatment, and every one attended later for assessment of the results, so we have a $100 \%$ follow-up.

At the outset of this investigation the problem of a control series was discussed. It was considered that as so many variable factors were concerned, such as the age, weight, and general physical condition of the patients, and the type of arthritis, its severity, and the activity or quiescence of the disease, very large numbers of patients would be required to provide reliable comparisons. The treatment of bilateral affections where one side could be treated by the salicylate injection and the other by, for example, the oily base alone is possibly better scientifically, but was abandoned for practical considerations. It was therefore decided to use the patients themselves as their own controls. On the first examination, before treatment was begun, the assessor closely questioned the patients about the amount of pain and their various activities at the time and six months earlier. After treatment the same questions about pain and activity were asked again. Although this method results 
in a comparison of subjective symptoms only, it gives a picture of the trend of symptoms without and with treatment in the same patients.

\section{Treatment}

All the patients were treated by intra-articular injections of benzyl salicylate in oil, given at weekly intervals for six weeks. Three knees received seven weekly injections, two knees eight injections, and five knees had two six-weeks courses. Eighteen knees received an intraosseous injection in addition to the six-weeks course, and one patient who had both knees treated had the course and two intraosseous injections. The indication for giving an injection into the bone was persistence of pain as the main symptom, after completion of the intra-articular course.

The solution used for the intra-articular injections was that used by Scott :

$$
\begin{array}{lllr}
\text { Benzyl salicylate } & . . & \ldots & 5 \% \\
\text { Camphor } . & . & \ldots & 5 \% \\
\text { Arachis oil } & . & \ldots & \text { to } 100 \%
\end{array}
$$

It was used in doses of 0.1 to $0.3 \mathrm{ml}$., injected from a tuberculin syringe without an anaesthetic, or through an intradermal weal of procaine. If an effusion was present in the joint aspiration preceded the injection.

For the intraosseous injections the formula was :

$\begin{array}{lllr}\text { Salicylic acid } & . & . & 0.2 \% \\ \text { Sodium citrate } & . & . & 1 \% \\ \text { Chlorbutol } & . & . & 0.5 \% \\ \text { Phenol red } & . & . & 0.2 \% \\ \text { Distilled water } & . . & . & \text { to } 100 \%\end{array}$

This solution was used in doses of 50 to $80 \mathrm{ml}$., the dose being divided between the femur and the tibia. In the femur the injection was given into the medial condyle below the adductor tubercle. In the tibia the site was the medial condyle two fingerbreadths below the joint line and just anterior to the tibial collateral ligament. The injection was given into the subcortical areas of the bones. Immediately before injection 150 turbidity-reducing units of hyalase were added to $100 \mathrm{ml}$. of the aqueous solution. A general anaesthetic is necessary, as this is a painful injection. If local tenderness was severe the periosteum in the tender area also was infiltrated with 1 to $5 \mathrm{ml}$. of the oily solution in divided doses.

\section{Results}

Of the 53 patients treated 12 were male and 41 female. Their ages ranged from 34 to 79 , the average being 62 . During treatment it was found that one patient was suffering from gout (blood uric acid $7.1 \mathrm{mg} . / 100 \mathrm{ml}$.) and another from rheumatoid arthritis (E.S.R. $48 \mathrm{~mm}$. in one hour, Westergren). Both these cases gave unsatisfactory results from the injections, but have been included in the survey and analysis as they were originally accepted, although they have weighted the results slightly on the unfavourable side.

While recognizing the difficulties of exact diagnosis, and the fact that some of the features of one type of arthritis may be present when the condition is, in the main, of another type, diagnoses were made as accurately as possible, and were as follows: primary generalized osteoarthritis (Kellgren), 27 ; osteoarthritis, 24 ; gout, 1 ; rheumatoid arthritis, 1 . The number of knees treated was 88 .

It was our intention to review the patients six months after completion of their treatment. However, some patients began their treatment later than was expected, and others had more prolonged treatment. In the whole series the average time between completion of treatment and reexamination was six months: for $\mathbf{4 2}$ knees it was less, and for 46 more than six months. A detailed clinical analysis (Table I) was made in each case before and after treatment, along the lines described by Shepherd (1954).

Five categories of pain were recognized: (1) none, (2) slight enough to ignore, (3) patient makes concessions to the pain, (4) pain causes disablement, (5) pain is absolutely crippling (see Table II).
To estimate function a series of questions on everyday activities were put to the patient. These elicited the distance a patient could walk, and the type of aid, if any, required in walking; the ability to use stairs, to kneel, to put on shoes, to take a bath; and the patient's usual work or acţivities in general. Inability to perform these actions in part or entirely was shown in the record by placing a black mark or marks against the action. The sum of these marks is a method of comparing function-the higher the number of marks the worse the function (see Table III).

Physical signs-heat, tenderness, effusion into the joint, and range of movement (Table IV)-were noted.

The patient's own assessment after treatment was classified as " enthusiastically pleased" in 35 cases, "pleased" in 29 , "doubtful about the value" in 15 , and "considered not worth while" in 9 .

\begin{tabular}{|c|c|c|c|c|c|c|c|}
\hline \multicolumn{4}{|c|}{$\begin{array}{l}\text { Alteration in } 6 \text { Months Prior to } \\
\text { Treatment }\end{array}$} & \multicolumn{4}{|c|}{$\begin{array}{c}\text { After Treatment-Gradod } \\
\text { Results }\end{array}$} \\
\hline $\begin{array}{l}\text { Better } \\
\text { Slightly better }\end{array}$ & $\begin{array}{l}4 \\
2\end{array}$ & Improvod & 6 & $\begin{array}{l}\text { Excellent } \\
\text { Good .. } \\
\text { Fair }\end{array}$ & $\begin{array}{l}24 \\
27 \\
16\end{array}$ & & 67 \\
\hline $\begin{array}{l}\text { Same } . . \\
\text { Slightly worse } \\
\text { Worse }\end{array}$ & $\begin{array}{l}35 \\
28 \\
19\end{array}$ & \} $\begin{array}{c}\text { Same or } \\
\text { worse }\end{array}$ & 82 & Poor .. & 21 & $\begin{array}{c}\text { Same or } \\
\text { worse }\end{array}$ & 21 \\
\hline \multicolumn{8}{|c|}{ TABLE II.-Pain } \\
\hline \multicolumn{4}{|c|}{$\begin{array}{l}\text { Alteration in } 6 \text { Months Prior to } \\
\text { Treatment }\end{array}$} & \multicolumn{4}{|c|}{$\begin{array}{c}\text { Alteration after } \\
\text { Treatment }\end{array}$} \\
\hline Better .. & 10 & Improved 1 & 10 & $\begin{array}{l}\text { Very much } \\
\text { better } \\
\text { Much better } \\
\text { Better }\end{array}$ & $\begin{array}{l}15 \\
34 \\
19\end{array}$ & Improved & 68 \\
\hline $\begin{array}{ll}\text { Same } & \cdots \\
\text { Worse } & \cdots\end{array}$ & $\begin{array}{l}45 \\
33\end{array}$ & \} $\begin{array}{l}\text { Same or } \\
\text { worse }\end{array}$ & 78 & $\underset{\text { Worse }}{\text { Same }}$ & $\begin{array}{r}17 \\
3\end{array}$ & $\left\{\begin{array}{r}\text { Same or } \\
\text { worse }\end{array}\right.$ & 20 \\
\hline
\end{tabular}

Table I.-General Condition of 88 Affected Knees

Very much better $=$ Two or more categories better. Much better $=$ On category better. Better = Same category, but patient says better. Worso= Same category, but patient says worse.

\begin{tabular}{|c|c|c|c|c|c|c|}
\hline \multicolumn{4}{|c|}{$\underset{\text { Alteration in } 6 \text { Months Prior to }}{\text { Treatment }}$} & \multicolumn{3}{|c|}{$\begin{array}{c}\text { Alteration after } \\
\text { Treatment }\end{array}$} \\
\hline Better & $\ldots$ & Improved & 3 & $\begin{array}{lr}\text { Very much } & \\
\quad \text { better } & 7 \\
\text { Much better } & 29 \\
\text { Better } & 19\end{array}$ & Improved & 55 \\
\hline $\begin{array}{l}\text { Same } \\
\text { Worse }\end{array}$ & $\begin{array}{l}48 \\
37\end{array}$ & \} $\begin{array}{c}\text { Same or } \\
\text { worse }\end{array}$ & 85 & $\begin{array}{l}\text { Same } \\
\text { Worse }\end{array}$ & \} $\begin{array}{c}\text { Same or } \\
\text { worse }\end{array}$ & 33 \\
\hline
\end{tabular}

TABLE III.-Function by Performance

Very much better = Seven or more black marks less. Much better = Threo to six black marks less. Better = Two black marks less.

\begin{tabular}{|c|c|c|c|c|}
\hline \multicolumn{2}{|l|}{ Worse } & $\begin{array}{c}\text { Same } \\
\text { (Within } 10^{\circ} \text { ) }\end{array}$ & \multicolumn{2}{|l|}{ Better } \\
\hline $\begin{array}{ccc}\text { Decreased by } & 10-19^{\circ} \\
\text { ", } & \text { ", } & 20-29^{\circ} \\
\text { " } & 30-39^{\circ}\end{array}$ & $\begin{array}{l}8 \\
1 \\
1\end{array}$ & 56 & $\begin{array}{cc}\text { Increased by } 10-19^{\circ} \\
" \quad \text { " } 20-29^{\circ} \\
" \quad 30-39^{\circ} \\
" \quad \text { " } 40-49^{\circ}\end{array}$ & $\begin{array}{r}10 \\
9 \\
2 \\
1\end{array}$ \\
\hline Total & 10 & 56 & & 22 \\
\hline
\end{tabular}

TABLE IV.-Movement (After Treatment)

The classification of results has been calculated according to a definite scheme, taking into account these four criteria - pain, function, physical signs, and the patient's own assessment. This scheme has been devised and strictly enforced to ensure that there is no tendency to overestimate in the tables the benefits of the treatment-rather the reverse. The overall grading of results (Tables V-VIII) may be broadly defined as follows: excellent (very marked improvement) ; good (marked improvement); fair (improved-in the assessor's opinion the treatment has been worth while); poor (minimal or no improvement -in the assessor's opinion the treatment has not been worth while). 
TABLB V.-Diagnoses and Grading

\begin{tabular}{|c|c|c|c|c|c|}
\hline \multirow{2}{*}{\multicolumn{2}{|c|}{ Diagnosis }} & \multicolumn{4}{|c|}{ Grading After Treatment } \\
\hline & & Excellent & Good & Fair & Poor \\
\hline $\begin{array}{l}\text { Primary generalizied oste } \\
\text { Osteoarthritis } \\
\text { Rheumatoid arthritis } \\
\text { Gout } \quad \text {.. } \quad \text {.. } \\
\end{array}$ & 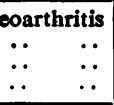 & $\begin{array}{r}17 \\
7\end{array}$ & $\begin{array}{l}17 \\
10\end{array}$ & $\begin{array}{r}4 \\
10 \\
2\end{array}$ & $\begin{array}{r}10 \\
9 \\
2\end{array}$ \\
\hline Total & $\ldots$ & 24 & 27 & 16 & 21 \\
\hline
\end{tabular}

TABLB VI.-Sex and Grading

\begin{tabular}{ll|c|c|c|c|c}
\hline & & Excellent & Good & Fair & Poor & Total \\
\hline Male & $\because$ & 3 & 5 & 4 & 5 & 17 \\
Female & $\because$ & 21 & 22 & 12 & 16 & 71 \\
\hline
\end{tabular}

TABLB VII.-Ages and Grading

\begin{tabular}{|c|c|c|c|c|c|c|}
\hline Ages & & Excellent & Good & Fair & Poor & $\begin{array}{l}\text { Total No. } \\
\text { of Knees }\end{array}$ \\
\hline $\begin{array}{l}\text { Over } 70 \\
60-69 \\
50-59 \\
40-49 \\
30-39\end{array}$ & $\begin{array}{l}\ddot{ } \\
\because \\
\because\end{array}$ & $\begin{array}{r}13 \\
5 \\
4 \\
2 \\
-\end{array}$ & $\begin{array}{r}7 \\
6 \\
11 \\
3 \\
-\end{array}$ & $\begin{array}{r}2 \\
10 \\
3 \\
\frac{1}{1}\end{array}$ & $\begin{array}{r}10 \\
8 \\
3 \\
-\end{array}$ & $\begin{array}{r}32 \\
29 \\
21 \\
5 \\
1\end{array}$ \\
\hline
\end{tabular}

TABLE VIII.-Length of History and Grading

\begin{tabular}{c|c|c|c|c|c}
\hline $\begin{array}{c}\text { Length } \\
\text { of History }\end{array}$ & \multicolumn{5}{|c}{ Grading } \\
\cline { 2 - 6 } & Excellent & Good & Fair & Poor & Total \\
\hline $\begin{array}{c}\text { Under 3 years.. } \\
\text { Over 3 }\end{array}$ ".. & 13 & 11 & 13 & 9 & 46 \\
\hline
\end{tabular}

\section{Comment}

All the patients had, of course, come to hospital for treatment of their knee-joint disability. Very few therefore had improved during the six months before treatment. Allowance must be made for the fact that patients desiring treatment are not likely to minimize their complaints, while after any kind of treatment they are inclined to state that they have improved, even though this be really only evidence of wishful thinking.

The figures in the Tables do not represent scientifically accurate comparisons, but they suffice, we think, to indicate that there is value in the treatment.

The treatment itself is not pleasant, causing a temporary exacerbation of local symptoms and also considerable general malaise in many cases. If this is borne in mind, the patient's own assessment is of significance.

Function by performance was often more an index of general fitness than an indication of the function of the knee-joint. For example, a stout, almost blind, and very deaf old lady of 76 was wheeled up in her chair for both pre- and post-treatment examinations. She was very pleased with the results of the treatment. Pain, from having been of disabling severity in both knees, was reduced to none at all in one knee and to a negligible amount in the other. One knee had improved more than 20 degrees in its range of movement. Though this had made her much more comfortable, little change in function was possible owing to her other disabilities.

No significant difference was detected in the results between the group. of cases who had completed treatment more than six months before the assessment and those treated less than six months before. No significant changes were found in pre- and post-treatment radiographs.

Eighteen knees received intraosseous injections after completing the standard course of intra-articular injections. The graded results in these were very similar to the graded results of the whole series shown in Table $I$.
All cases had clear radiological evidence of osteoarthritis, and the assessment of results has been based on strict criteria. In Table I a " fair" result indicates some improvement in the assessor's opinion, and on this basis 67 out of 88 knees were improved by treatment, yet only six had improved in the six months before treatment. Pain was definitely less in 68 of the knees treated, but in only 10 over the period of six months prior to treatment. If the two cases of gout and rheumatoid arthritis are excluded, as they should have been by more careful differential diagnosis before treatment, the results become even more impressive. The fact that every patient treated was prepared to attend again for reassessment several months later is significant: many had to travel considerable distances to do so.

\section{Discussion}

Is it possible to give some reasonable explanation of how this benefit has been produced ? The improvement cannot be due to a simple local analgesic effect, as it did not occur until at least 24 hours after the intra-articular injection and was usually not noticed until after the third or fourth injection. Sometimes it was even postponed until after an intraosseous injection. When pain is relieved the patient is able to use the knee more. Function is in itself an aid to further recovery.

Scientific attention has recently been focused on the action of salicylates. Trethewie $(1951,1954)$ threw much light on the possible reasons for their effectiveness in rheumatic disorders. He proved that sodium salicylate and acetylsalicylic acid inhibit the release of histamine and similar substances. Apart from the importance of this work in relation to allergic phenomena it may well be that histamine or histamine-like substances resulting from tissue breakdown play a part in the production of symptoms in osteoarthritis. The ingestion of salicylates by mouth might well relieve symptoms in osteoarthritis by retarding the production of histamine-like substances, but a very large dosage would be required continuously to secure their inhibition. Local injection produces a high concentration of the salicylate at the point where its action is required. Scott (1938) showed that the use of oil as a solvent greatly slowed the absorption and excretion of salicylate.

The intraosseous injection probably acts both generally and locally. "There is undoubtedly a rapid flooding of the blood stream with salicylate. Harrison and Gossman (1955) showed by experimental work that this happens in the cadaver. In living subjects the rate of entry into the larger veins must be even more rapid. An opaque injection was shown by the same authors to fill up a network of small veins surrounding the adjacent joints. From periarticular veins and venules the salicylate may exert a local effect. A similar local spread has been described by Heald (1951).

The clinical results in our series appear to justify further investigation of this method, which it is hoped this paper may stimulate.

\section{Summary}

A review is given of solutions which have been used in the injection treatment of osteoarthritis, and of the results obtained by their use.

Laughton Scott's methods of intra-articular and intraosseous injection are described.

The clinical results in 88 osteoarthritic knees in 53 patients treated by this method are analysed by an assessor not concerned in either the selection of the cases or their treatment.

The results obtained by this method appear to be encouraging.

The possible mode of action of the solutions used is discussed. 
REFERENCES

Andernach, F., and Löhr, W. (1936. Zbl. Chtr., 63, 2493.

Baker, D. M.. and Chayen, M. S. (1948). Lancet, 1, 93.

Broadman. J. (1954). J. med. Soc. N.J., 51, 320.

Crowe, H. W. (1944). Lancet, 1, 563.

Desmarais, M. H. L. (1952). Ann. rheum. Dis., 11, 277

Elkin. A. C. (1945), Med. Press, 213, 350.

Harrison, R. G., and Gossman, H. H. (1955). J. Bone Jt Surg., 37B, 150 Heald, C. B. (1951). Lancet, 2, 659 .

$\overline{\text { Konig }}$ and Martia, A. J. (1947). Ibid., 2, 110.

Konig, W. (1932). Zbi. Chtr., 59, 1907.

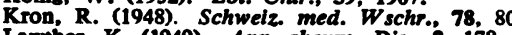

Lawther, K. (1949). Ann. rheum. Dis., 8, 178

Mawson, R. (1946). Brtt. med. J., 2, 691.

Nicholson, D. P. (1948). Ann. rheum. Dis., 7, 28.

araf, J., Abaza, A., and Peretz, E. (1949). Bull. Soc. med. Hóp. Parls.

Scott, G. L. (1938). Practittoner, 140, 307.

The (1943). Brit. med. J., 2, 510 .

(1954). J. Bone Jt Surg., 36B, 354.

bid., 15, 483

Trethewie, E. R. (1951). Aust. J. exp. Bioi. med. Sci., 29, 443.

Wavis). Med. J.A Aust., 1, 388.

Waugh, W. G. (1938). Lancet, 1,487

\section{THIOPENTONE SENSITIVITY AND DYSTROPHIA MYOTONICA}

BY

A. B. LODGE, M.B., B.S., D.A.

Department of Anaesthesia, St. Bartholomew's Hospital, London

Since its introduction to clinical practice in 1934, thiopentone has come to be used universally on a very large scale for the induction of general anaesthesia and also as the sole anaesthetic agent for certain short operative procedures. After initial setbacks the common dangers attendant upon the use of the drug are now well appreciated. These dangers are many, and anaesthetists have written at length concerning the use and abuse of thiopentone. In addition to the common dangers there are a number of rare conditions which put the patient at risk when thiopentone is used. Amongst these may be mentioned porphyria, myasthenia gravis, Addison's disease, and dystrophia myotonica.

Dystrophia myotonica is a rare disease, but many practitioners must know of cases amongst their patients, and, in spite of its rarity, it is felt that the extraordinary sensitivity towards thiopentone shown by subjects with this disease should be brought again to the attention of all who are in the habit of using the drug.

The literature contains reference to only four instances of the use of thiopentone in dystrophia myotonica. A further case is recorded, and I have knowledge of two other persons who suffer from the disease.

\section{Dystrophia Myotonica}

Dystrophia myotonica is a hereditary familial disease affecting both males and females and usually appearing between the ages of 15 and 35 years. It does not of itself materially shorten life, but death usually occurs during the fifth decade from intercurrent infections. The features of the disease can be grouped under three heads.

1. Myotonia.-An involuntary persistence of muscular contraction following its voluntary initiation. It may be present in any group of muscles and is intensified by acetylcholine and by neostigmine and potassium.

2. Muscular Atrophy. - This quite characteristically involves the sternomastoids and facial muscles. Also involved may be the muscles of the shoulder-girdle, forearms, and hands, the quadriceps femoris, and the leg muscles below the knees. The atrophy is usually symmetrical on the two sides of the body; the affected muscles are weak but show no fibrillation. Tendon reflexes are diminished or absent. The rate of development is variable, usually proceeding over a period of some years, but it may be much more rapid. The wasting bears no constant relationship in either time or site to the myotonic symptoms.

3. Others.-Cataract appears in about $50 \%$ of cases, and may be seen in otherwise healthy siblings of those who show the muscular changes. It tends to appear at an earlier age in successive generations. Premature frontal baldness is a common feature, as also are ovarian and testicular atrophy. Less frequently seen are adenomata of the thyroid, diabetes mellitus, and abnormalities of the pituitary and adrenals. Mental changes are often present.

Histologically the disease has been shown to be confined entirely to the muscles; neither the central nor the peripheral nervous system shows any abnormality. There is no uniform atrophy of muscle fibres; healthy and degenerating fibres are seen side by side. Some fibres appear larger than normal, and in the early stages of degeneration show loss of transverse striation with proliferation of sarcolemmal nuclei ; eventually the fibre is completely replaced by fat and connective tissue.

Diagnosis of the developed case is simple. When myotonia precedes muscle-wasting, the age of onset will distinguish it from Thomsen's disease (myotonia congenita). In the absence or late development of myotonia, the sternomastoid wasting is characteristic.

No treatment will arrest the progress of the disease. Quinine, $10-30 \mathrm{gr}$. $(0.65-2 \mathrm{~g}$.) daily is said to improve the myotonia, and the use of procaine amide has been reported (Geschwind and Simpson, 1955).

\section{Case History}

A woman aged 30, who had suffered from dystrophia myotonica for 14 years, had the classical features of myotonis and facial and sternomastoid wasting, and was of above average intelligence. She was to undergo an abdominal operation. Premedication, given one hour pre-operatively, with pethidine, $100 \mathrm{mg}$., and scopolamine, 1/150 gr. (0.43 mg.), did not appear to have unduly depressed her in any way. General anaesthesia was induced with $2.5 \%$ thiopentone, and a dose of $100 \mathrm{mg}$. was given. This dose produced loss of consciousness and apnoea, the latter lasting for 20 minutes, and thereafter respirations remained depressed for a further 20 minutes. The apnoea was accompanied by a state of complete muscular flaccidity comparable to complete curarization-direct laryngoscopy being easily possible. The quality and rate of the pulse remained unaltered during inflation with nitrous oxide and oxygen, and there was nothing to suggest wakening. Subsequently the response to D-tubocurarine was normal.

\section{Discussion}

This case, which was referred to by Langton Hewer (1957), corroborates the experiences of the three authors who have previously reported the idiosyncrasy. Dundee (1952) reports three cases, and Bourke and Zuck (1957) the fourth.

It has been found that in dystrophia myotonica normal doses of thiopentone cause profound depression of respiration amounting to apnoea. Doses of $500 \mathrm{mg}$. produced apnoea lasting 10 minutes in one of Dundee's cases, and lasting two hours in Bourke and Zuck's case ; in both there followed a prolonged period of depressed respirations insufficient to maintain adequate oxygenation. These three authors were also able to show that so small a dose as $50 \mathrm{mg}$. of thiopentone produced a very marked depression of respiration almost amounting to apnoea, without producing loss of consciousness. The normal transient initial stimulation of respiration is not seen.

It is not intended to suggest that the use of thiopentone should be abandoned for this type of patient, though it is possible that some of the unexplained deaths occurring during thiopentone induction and anaesthesia could be attributed to this hypersensitivity. It is intended rather to point out the hazards, to emphasize certain basic principles, and to suggest that this rare disease may not in fact be exceedingly rare. To suspect every case of premature baldness or thyroid adenoma may be overcautious, but the 